\title{
THE FARMING OF MAORI LANDS
}

\section{CHARLES GOLDSMITH, Te Araroa}

We have seen how the Maori inherited his land and how through the process of succession the numbers of the owners increased. How were lands with such a multiplicity of ownership to be farmed? Any one owner could start something 'on his own account, and so could everyone else in the block who had a mind to do so. Trouble started and no one got anywhere. The solution lay in leasing to one of the owners, or some other Maori or European, or by incorporating the block.

By the latter means, the Committee of Management could borrow money and farm the land in the interests of all the owners. One block with over 500 owners comprising 16,100 acres of virgin country in the Matakaoa County was incorporated in 1913, with the late Sir Apirana Ngata as the Chairman of the Committee of Management. He was empowered by the Court to borrow on the security of the freehold for the purposes of surveying and development. The block was subdivided into 13 allotments, a community woolshed built, and yards and dip erected.

The Committee then granted leases of 21 years with right of renewal to selected and approved owners who had gained knowledge and experience of farming methods from other incorporations or European settlers, especially from the late $\mathrm{Mr} \mathrm{T}$. S. Williams, the "father" of Maori farming on the East Coast. The lessees were in their turn granted loans from the bank on the security of their leases and stock, backed up by guarantees from the Block Committee. The rents were paid into the bank in reduction of the debt, and later for distribution to the owners as rent.

There was no road access. Everything had to be packed in or brought in from ships by surf boats, which was the only way also of getting the wool out. The land was extremely rough, with steep hills and gullies, with small stretches of flat land, and sand dunes along the sea coast. Fairly large tracts of bush still remain, being too rough to fall. The genius of Apirana Ngata conceived the plan and his unique ability of organising the people and his persuasiveness with the bank enabled farming of this land to become a fact. He utilised men who had had practical experience in the breaking in of new country and the handling of stock, for their own benefit and to set the example to the younger men. The leases have expired. 
Some of the farms were kept in good order, but some were neglected and reverted to second growth, manuka, and tauwhinu. Under the Consolidation Scheme new titles were completed in 1957 and the owners drafted off into the various allotments for the farming of which they are now responsible.

Some have decided to lease to one of themselves. Some are applying to the Maori Affairs Department to come under its Development Scheme. Others are already firmly established with some of the stock companies. Thus where there was one title with so many hundred owners, there are now fifteen with a reasonable number of related owners. This should lead to greater interest and concentrated effort in the farming of this area.

The incorporating of large blocks of Maori land was not begun here. All the way up the coast, from Whangara to the Waiapu River, they had been set up at the beginning of the century. Many have proved very successful and are still in existence. In the Waiapu valley the Maoris reacted vigorously under the leadership and practical guidance of Apirana Ngata. The work on thousands of acres was done solely by the Maoris, from the clearing, grassing, and fencing to shepherding and shearing. On most of the stations Ngata did the buying and selling of the stock. He, with others, had been well schooled in the art of culling and the picking of fats, and in the handling and classing of wool. The Romney cross sheep was found to be the best suited to the country and the climate. Carefully selected rams from stud farms put to ewes from the Williams' flocks evolved a fine type of sheep which in their day were known as some of the best on the coast, Surplus stock from these farms helped to start off other Maori farmers as they brought in their lands. The farming fever had taken a strong hold. It spread through the Waiapu County into Matakaoa. The Maori was told that he would have to use his land, or lose it.

One group living at the mouth of the Waiapu River in the East Cape area possessed tribal rights to a block of some 10,000 acres, but which at that time had not yet been through the Maori Land Court. They appealed to Apirana Ngata, who was then their Member of Parliament. They, too, wanted to work their land, but there was no title. A meeting of the potential owners was held and an agreement arrived at whereby certain families were allocated areas in the block where their family claims lay. They could occupy these areas until the land was put through the Court and they could then get proper leases. Ten families started off on this understanding round about 1906. Having no tenure, they could not raise money on the land. The families did their own work, and managed to get some assistance from the local storekeeper, the only one in the area then. He financed their stock 
purchases and handled all the produce. He had everything his own way and charged 10 per cent interest and more.

I will trace the record of one family of four brothers as near as I can from notes in my possession. They began by felling 50 acres of bush. They got seed by cutting ryegrass from a nearby field belonging to a relative. They managed to procure some sheep through Apirana Ngata. The next year they felled 100 acres, and sowed it with seed from the previous burn. Thus they went on until by about 1910 they had cleared, grassed, and fenced about 500 acres. Then they were able to let out some of the work by contract. By the time World War I came along, they had the whole of the area allocated to them, about 1,500 acres, cleared, grassed, and fenced into three big paddocks and a central one of about 100. My written records start from 1920. That year they wintered 3,470 sheep and 140 cattle. They sent to the works 1,160 sheep. The next season they sent 1,262 fats and sold 534 stores, the wool clip being 61 bales. There was no road access. The sheep had to be driven over two miles of hill tracks, then along a three mile beach to the woolshed for shearing. They picked their own fat sheep, which were then driven to the Tokomaru Bay Freezing Works 40 miles away, until 1926 when they went to the Hicks Bay Works which had just opened, about 30 miles distant. The land at this time was still highly productive, but tauwhinu and manuka were beginning to show on the higher hills. The paddocks were too big and there were not enough cattle. The main objective was to carry as many sheep as possible, with the consequence that the clovers were getting eaten out and danthonia was replacing the English grasses. By 1938 they were wintering only 1,850 sheep and the clip had fallen to 27 bales. Twenty years later the carrying was reduced to 1,400 sheep and the clip to 22 bales. A year later the last surviving brother died, and the title to the land had not yet been finalised. It was not possible to obtain a lease. The position of the other squatters was the same as the one set out. The first judgment of the Maori Land Court was given in 1912 and was immediately appealed against. It became the subject of appeals and petitions until the death of the chief litigant in 1954.

The way was open at last to the Northern Waiapu Consolidation Scheme which comprised this block and all Maori lands in the Matakaoa County and along the northern verge of the Waiapu County.

By 1958 the new titles were practically completed and the settlers were now obliged to get leases or sell their stock. One or two families were able to freehold their farms and will carry on. two groups owning over 4,000 acres have asked the Maori Affairs Department to have the land brought under its Development 
Scheme and this is under way. Other groups are considering taking this step too. The land has deteriorated so much, and financial backing well-nigh impossible, the Development Scheme appears to be the only answer. The trouble in this case arose out of the inability to secure leases owing to the endless law suits in the Maori Land Court, which some say cost more than the land was worth. The demise of the old hands had something to do with the farms slipping. Many of their promising sons went away to war and did not return. Much of the incentive was gone.

When Apirana Ngata initiated the farming of Maori lands on the East Coast, the soil was new and rich and results were quick. The manhood was strong and willing to learn and became the backbone of the local economy. All projects were on the community level-the farms, the stock, the store, the picture hall belonged to the people. Young men were sent away to colleges, to Lincoln, to Hawkesbury, to learn more about farming and agriculture, at the expense of the stations. They came back to jobs on the farms. The idea of the individualisation of land began to show itself. Ngata himself realised the need of it. He started the consolidation of interests in lands from Waipiro Bay to the Waiapu River about 1925. By 1928 it was completed, a gigantic task which only he could have accomplished. Thus the communal farms were dissected and gave way to family and individual holdings. These were more suited to dairying. So he started the Ngatiporou Dairy Company with money borrowed from the Maori Trustee on the security of two of the remaining larger incorporations, this being eventually repaid as suppliers' shares were taken up. Bulls and Jersey heifers were imported from tested Taranaki herds. A new industry had started and everyone was keen. Many of the newly consolidated owners were financed by the Maori Trustee or became units under the Development scheme. Some were started off by the dairy company, the Waiapu Farmers, and other means. Cream began to come in from suppliers as far away as Potaka, 45 miles to the north of Ruatoria, where the factory was, and from Te Puia, 16 miles to the south. Then the 1930 slump came, and some were knocked back. By 1948 the number of suppliers had dwindled. The high prices for sheep and the bumper wool prices of 1950-51 caused many to switch. The defections from dairying are still going on, so much so that the fate of the dairy company is precarious, a company which was the pride of its creator. The old order has passed away, and with it Ngata and the men of his generation. They had been nurtured in the old tribal customs and traditions. The welfare of the tribe, the "hapu", was the mainspring of their lives.

Now it is mostly each Maori for himself. Many of them are good farmers, on their own freehold, or on leaseholds of either 
Crown or Maori land. Given the opportunity on good land and finance with reasonable supervision and sound advice, he will turn out all right. He can work and is generally good with his hands.

Here is an instance of a Maori farmer who bought the leasehold of 865 acres in the East Cape district. It comprised roughly 800 acres of flats and foothills, and the rest bush-covered hills. It was carrying then 700 sheep. The flats were mostly in scrub and rushes. By 1928, with the help of his brothers, he had cut most of the scrub, felled the bush, and erected fences. By then he was carrying 1,900 sheep, 94 cattle, and the wool clip was 42 bales. By 1938 he had 1,810 sheep, 233 cattle, and the wool was 45 bales. By 1948 it was 2,017 sheep, 369 cattle and 61 bales. In 1958 he wintered 1,890 sheep, 285 cattle, and clipped

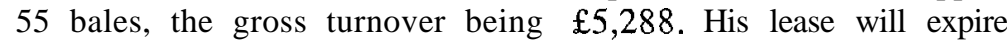
in 1963, and the land will go back to the Maori owners. This is a hard country to maintain, the tauwhinu being a perpetual nuisance. This man built his own house, woolshed, and yards. He raised a family on the place and now three sons are farming on their own account. His record shows perseverance, tenacity of purpose, and hard work. It may be that he and his wife both have pakeha blood.

There are many quite successful Maori farmers in the Waiapu and Matakaoa Counties, and it is significant that most are of mixed extraction. It is that bit of pakeha blood in him that prods the Maori. The trouble is that it is not always in the right direction. The problem of Maori lands and of its farming is in the essence of his title. Ownership in ancestral lands is not of his choosing; many present-day Maoris do not even know they are owners in some of his land. His farming ability must evolve with his character, his education, his appreciation of the finer things of life, and of values. He is by nature happy-go-lucky. He needs ambition to spur him on, and that generally comes with an injection of pakeha blood. It is a foregone conclusion that the Maori will in the dim future be absorbed into the white race. By that time the solution to his land problems may come to light.

\section{DISCUSSION}

Q. It is significant that Maori land will not come into its own until Maori and pakeha merge. What ideas have you whereby a young Maori man and woman can be made to realise farming is a worthwhile enterprise? More especially, haw can they be encouraged to take up farming, and how can they be trained to reach average pakeha farming standards?

A. Integration will take a long time. Maori farmers cannot wait for that, but they must get a title. The only way they can be made to appreciate the benefits of a higher standard of living is by education to pakeha standards. 
Q. (Smith, Gisborne): Would it be an advantage for the Department of Agriculture to take over a 1,500-2,000 acre property with its current problems of erosion and mineral deficiencies and farm it as a demonstration unit?

A. Yes. It has been suggested already that a training farm be established to demonstrate the benefits of market gardening and cropping in particular. If the Maori people can be shown what can be done in market gardening and cropping it would be a big step forward.

Comment (J. W. Woodcock): A system of farm improvement is already in operation on several farms in the area run by the Department of Agriculture.

Comment (C. J. Hamblyn): As I was instrumental in getting Mr Goldsmith to present his paper, I must congratulate him on his paper as he has given us a better understanding of Maori farming problems. There was good progress up to the slump. We have two farms run by the Department to a farm improvement plan. One is on hill country-a pakeha farm-and the other on the flats. On the hill farm, costs are very high. This work has been in progress for two years. The Department finances part and the farmer part. The purpose is to find out the cost of economic development. At Ruatoria a Maori farmer farms 84 acres. He used to produce 7,000-8,000 b/f per annum but has a potential of $17,000 \mathrm{~b} / \mathrm{f}$. This will be good for demonstration. We intend to take a good Maori hill block also. Horticulture enterprises would require the assistance of a horticulture instructor.

A. When Maoris are shown, they will follow.

Q. (Ford, Ruatoria): Is high cost of materials such as fencing, fertiliser and transport on the East Coast a hindrance to development of Maori lands?

A. I agree that costs are a big factor, but there is also the difficulty of obtaining finance for development, loan money is not readily available except to outstanding farmers. 